\title{
Will California's Landscapes Keep Working?
}

\section{The potential of "working landscapes" for conservation of rangelands was the subject of a public forum. Would a forum like this be useful in your area?}

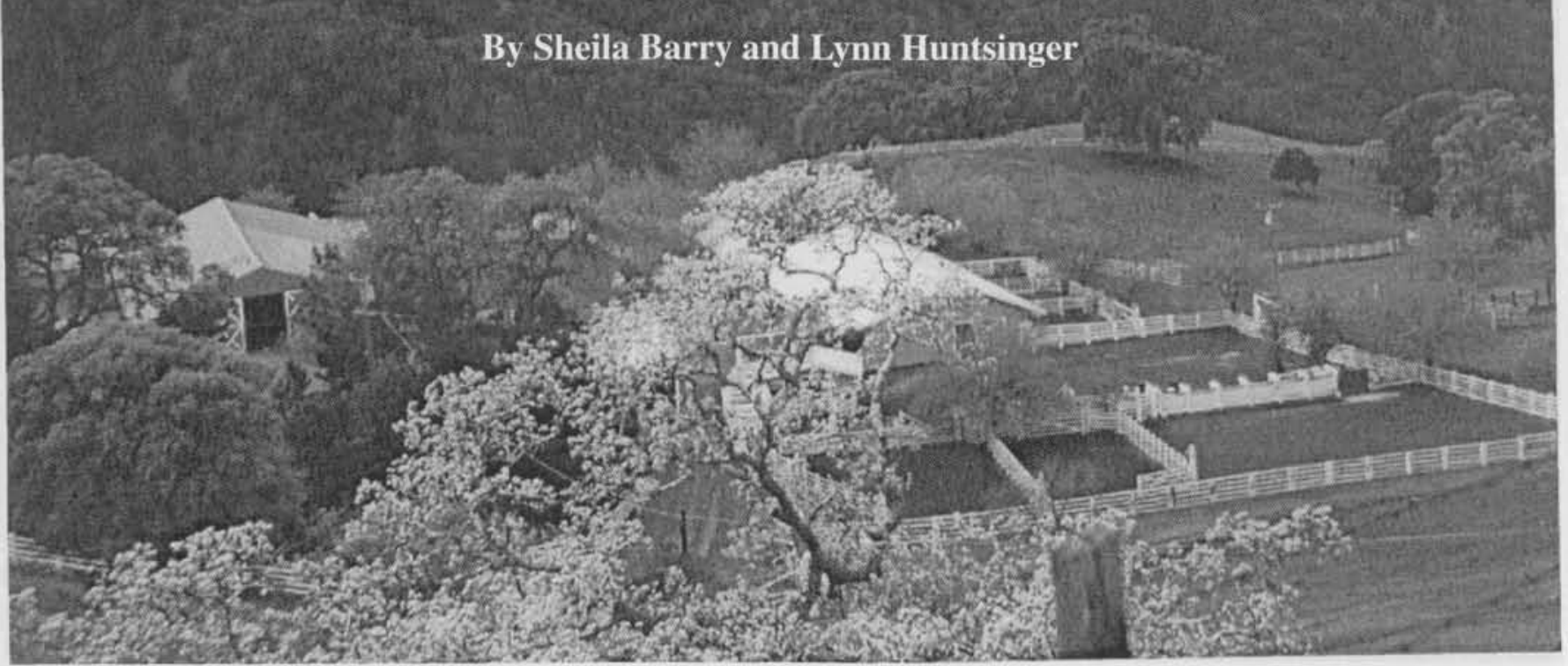

In California, oak woodland rangelands have a new "climax" state: ranchettes and housing developments. In fact, throughout the West urban encroachment threatens natural resource lands and rangeland landscapes.

Traditionally the alternative to uncontrolled land use change in areas with population growth has been to set aside land in parks or preserves. "Working landscapes" is a term coined to describe another alternative: deliberately maintaining land in farms and ranches.

In the fall of 2000 a forum was sponsored by University of California Cooperative Extension, the California Cattlemen's Association, The Nature Conservancy, and the California Rangeland Trust on "The Future and California's Working Landscapes." Community leaders, planners, educators, media representatives, and land managers were invited to learn and to share ideas about the role of working landscapes in open space management and protection in the oak woodlands and coastal foothills surrounding northern California's San Francisco Bay (Figure 1). The purpose was to begin a process of building support for working landscapes as a means of land conservation.

The existing programs of bonds, tax assessments, or grants to acquire land have proven to be increasingly expensive and impractical solutions to the problem of rangeland conversion. Land in the area is priced from several thousand to more than a million dollars per acre. Even if money is found to purchase a property, other costs continue to mount. Land management agencies lack management funds. Controlling noxious weeds, maintaining water developments, roads, and trails, and managing vegetation to reduce fire hazard requires personnel and funding. For example, the East Bay Regional Park District, which manages 92,000 acres in 59 regional parks, recreation areas, wilderness areas, shorelines, preserves, and land bank areas surrounding the San Francisco Bay, needs an annual budget of $\$ 80$ million to manage the land - a cost of $\$ 869 /$ acre.

Working landscapes, on the other hand, are productive lands that remain in private ownership. Income is realized from a sustainable natural resource industry, like ranching, but the open and undeveloped character of the landscape remains. Unfortunately, despite our long history of living off the land, much of the public seems to believe that being an observer is the best role for humans in a natural landscape. Yet it is likely that long-term conservation of rangelands and traditional rangeland uses will depend on public support for working landscapes.

Forum sponsors established a steering committee with broad representation, and the committee settled on a format that would allow maximum discussion and information sharing among the participants. Basically, three panels on pertinent topics would be followed by breakout groups to discuss and address questions about working landscapes. 


\section{The Forum Convenes}

After an introductory talk on the history and culture of ranching by Paul Starrs, author of Let the Cowboy Ride, the first panel of ranchers described the challenges they faced in coping with the current economic and regulatory situation, and the kinds of things they were doing to cope. Panelists had a chance to express their commitment to ranching as a way of life and to good stewardship.

Table. 1. What are the main difficulties in conserving open space?

The number in parentheses represents the average rank (1-4) among the groups. The lower the number, the greater the importance.

1. Escalating land values. (1.9) (most important difficulty) It is very expensive to purchase land for conservation.

For the private landowner, the financial incentives to develop are significantly greater than the economic return in trying to make a living off the land.

Local communities should share the burden of open space conservation.

2. Growing population pressure and urbanization. (2.2)

It is difficult to protect large tracts of land.

There is increasing competition for limited land resources.

3. Increasing costs to maintain and manage open space. (3.1) Land stewardship isn't compensated. Biological goals and values need to be integrated with economic viability for the landowners.

New economic opportunities are needed to support long-term viability of open space conservation.

4. Mutual lack of understanding and communication between landowners, public, government, agriculturalist, environmentalists, and developers. (3.3)

There can be an unwillingness to share information.

The impact of urbanization on agriculture is overlooked.

The ecological value of a working landscape is not often appreciated.

5. Conflicting and changing values regarding land use, including public policies versus private property rights. (3.5) (least important difficulty)

During the breakout session participants were asked, "What issues or problems do you see in conserving open space, including those you learned about this morning?" Breakout groups ranked problems from one as most important, to four as least important (Table 1).

The second panel showcased working ranches that are using grazing to achieve environmental objectives, and working with conservation organizations. During the following breakout session participants were asked, "How can working landscapes be used to conserve open space in the Bay Area?" (Table 2).

Dan Daggett, author of Beyond the Rangeland Conflict, spoke about working landscapes at lunch. Then the final panel discussed tools to sustain working landscapes, including conservation easements, niche marketing opportu-
Table. 2. How can working landscapes conserve Bay Area open space?

The number in parentheses represents the average rank (1-4) among the groups. The lower the number, the greater the importance.

1. Financial incentives for stewardship and to keep private ranchers on the land (not welfare for landowners). (2.1) (most important means)

Create value for good stewardship through direct payments, income or property tax breaks, or lower rent.

2. Community goal setting, visioning and planning. (2.8) Build coalitions to support working landscapes.

3. Promote multiple-use on existing open space, i.e. recreation, grazing, watershed,wildlife habitat to increase economic viability and long-term sustainability. (3.1)

4. Place lands in "permanent protection," such as conservation easements or public ownership. (3.1)

5. Develop and implement regional,watershed-based plans to identify and conserve important open space. (3.1)

6. Community education on local working landscapes. (3.3) Highlight successful working landscape examples.

Hands-on learning through field trips

Public meetings and workshops

7. Increase marketing opportunities for products from working landscapes, i.e. change current regulations to allow for direct marketing of meat, market locally-produced products. (3.6)

8. Reform land use policy, i.e. urban limit boundaries, zoning of open space subject to populace vote, minimum parcel size, subdivision controls. (3.7)

9. Include owners and managers of working landscapes to guide and inform local resource use issues. (3.8)

10. Encourage people who have an investment/connection to the land to continue wise stewardship. (3.9)

Make it easier for farmers and ranchers to pass their land to the next generation.

11. Promote and conduct collaborative research, i.e. ecological relationships, marketing, grazing and water quality impacts. (3.9) (least important means)

nities for ranchers, and partnerships. Participants were asked to brainstorm strategies to educate the public on working landscapes (Table 3).

\section{Who Came And What Did They Learn?}

The 125 people attending the Forum were surveyed before and after the meeting. We wanted to find out what kinds of people came, what they learned from the forum, and how to make improvements in future forums. Participants were diverse, with good representation from conservation groups, private business, and resource professionals (Table 4). The largest group was local and state government conservation or natural resource professionals.

Before and after surveys were used to evaluate the impact of the forum on the participant's perception of working 


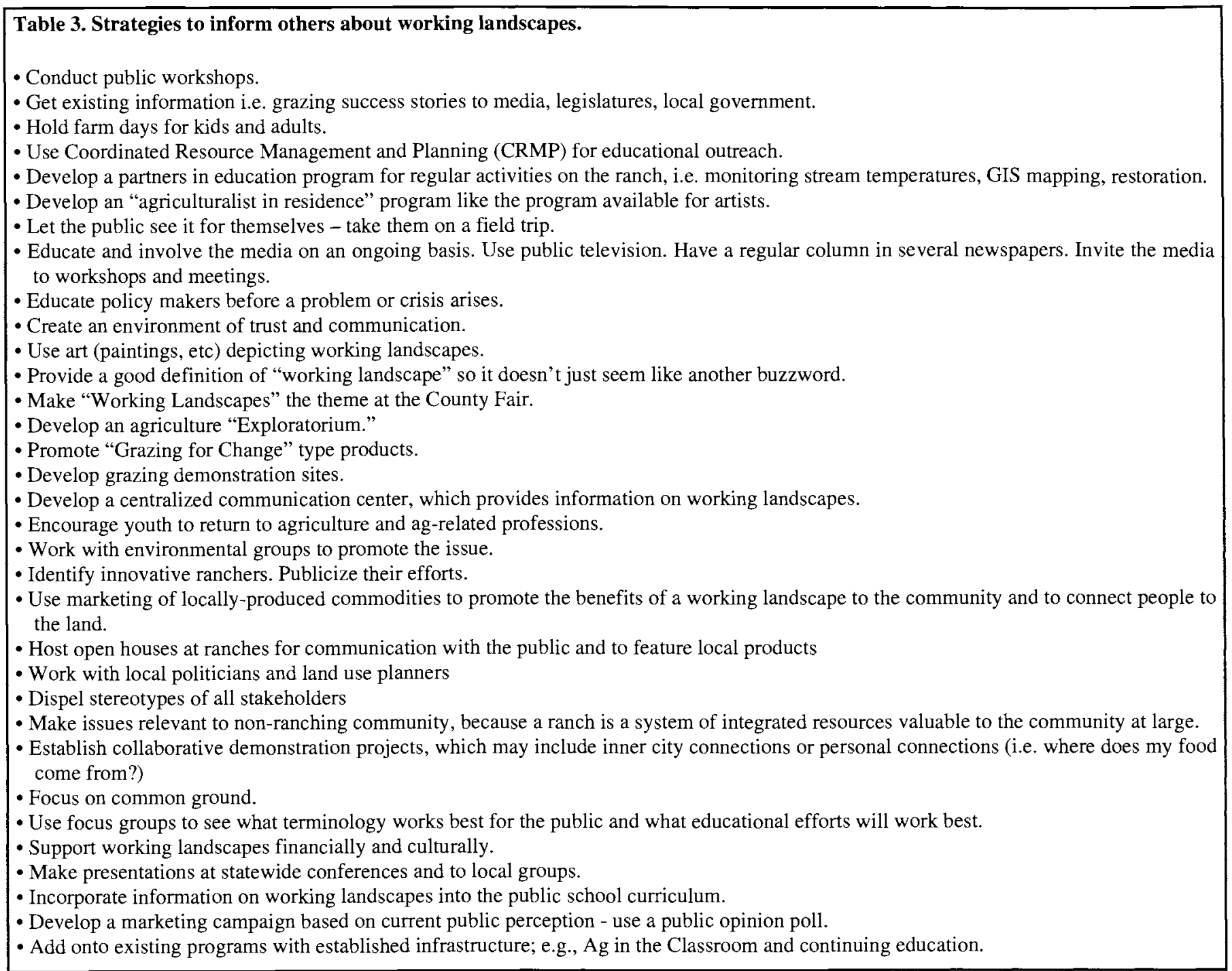

landscapes. Eleven questions were asked and evaluated. Responses to seven of them did not change significantly as a result of the forum (Table 5).

There was significant change during the forum in response to four of the questions (Table 6). The number of participants who were familiar with the concept of "work-

\begin{tabular}{|lc|}
\hline Table 4. Occupations of forum participants & \\
Extension or other advisory service & $11 \%$ \\
\hline Rancher or Farmer & $12 \%$ \\
\hline $\begin{array}{l}\text { Local or state govt. natural resource/conservation } \\
\text { professional }\end{array}$ & $23 \%$ \\
\hline Federal natural resource/conservation professional & $7 \%$ \\
\hline Municipal or regional utility or water district & $4 \%$ \\
\hline $\begin{array}{l}\text { Land Trust or Conservation (non-governmental } \\
\text { organization) NGO }\end{array}$ & $9 \%$ \\
\hline Other private organization or business & $18 \%$ \\
\hline University faculty and students & $14 \%$ \\
\hline
\end{tabular}

ing landscape" increased from $65 \%$ to $96 \%$ during the conference. The $8 \%$ of respondents who knew nothing at all about the concept initially, knew at least something about it by the end.

Before the conference $51 \%$ of respondents felt that maintaining a viable ranching community could be a somewhat to very successful way to conserve wildlife habitat and landscape in the Bay Area. Afterwards, that changed to $81 \%$ (Table 6). After the forum, participants believing that ranching had a long term future in the Bay Area increased also, from $42 \%$ to $64 \%$. Interestingly, the number thinking it was "very likely" that ranching had a long term future declined from $10 \%$ to $6 \%$, showing that some participants had become more familiar with the difficulties facing the ranching community.

Before the forum, $82 \%$ of respondents felt that conservation easements could be a somewhat to very successful way to conserve wildlife habitat and landscape in the Bay area. Afterwards, that changed to $96 \%$, with the greatest increase in those who thought it could be a "very successful" method. 
Table 5. Questionnaire responses that did not change significantly during the forum (percentages rounded).

Indicate how successful you feel each of the following strategies can be for wildlife habitat and landscape conservation in the Bay Area (circle one for each strategy):

\begin{tabular}{|c|c|c|c|c|}
\hline Land acquisition by the public & $\begin{array}{c}\text { Not at all } \\
\text { Successful } \\
8 \%\end{array}$ & $\begin{array}{c}\text { Possibly } \\
\text { Successful } \\
23 \%\end{array}$ & $\begin{array}{c}\text { Somewhat } \\
\text { Successful } \\
37 \%\end{array}$ & $\begin{array}{c}\text { Very } \\
\text { Successful } \\
33 \%\end{array}$ \\
\hline Land acquisition by private conservation organizations & $\begin{array}{c}\text { Not at all } \\
\text { Successful } \\
4 \%\end{array}$ & $\begin{array}{c}\text { Possibly } \\
\text { Successful } \\
14 \%\end{array}$ & $\begin{array}{c}\text { Somewhat } \\
\text { Successful } \\
47 \%\end{array}$ & $\begin{array}{c}\text { Very } \\
\text { Successful } \\
35 \%\end{array}$ \\
\hline Strong land use planning & $\begin{array}{c}\text { Not at all } \\
\text { Successful } \\
4 \%\end{array}$ & $\begin{array}{c}\text { Possibly } \\
\text { Successful } \\
31 \%\end{array}$ & $\begin{array}{c}\text { Somewhat } \\
\text { Successful } \\
27 \%\end{array}$ & $\begin{array}{c}\text { Very } \\
\text { Successful } \\
38 \%\end{array}$ \\
\hline Unrestricted marketing of land & $\begin{array}{c}\text { Not at all } \\
\text { Successful } \\
81 \%\end{array}$ & $\begin{array}{c}\text { Possibly } \\
\text { Successful } \\
15 \%\end{array}$ & $\begin{array}{c}\text { Somewhat } \\
\text { Successful } \\
0 \%\end{array}$ & $\begin{array}{c}\text { Very } \\
\text { Successful } \\
4 \%\end{array}$ \\
\hline Stronger governmental regulations for private land management & $\begin{array}{c}\text { Not at all } \\
\text { Successful } \\
19 \%\end{array}$ & $\begin{array}{c}\text { Possibly } \\
\text { Successful } \\
63 \%\end{array}$ & $\begin{array}{c}\text { Somewhat } \\
\text { Successful } \\
17 \%\end{array}$ & $\begin{array}{c}\text { Very } \\
\text { Successful } \\
2 \%\end{array}$ \\
\hline
\end{tabular}

Please circle one response for each of the following questions:

\begin{tabular}{|l|c|c|c|c|}
\hline $\begin{array}{l}\text { c. Do you think that grazing is compatible with conservation goals } \\
\text { like protecting wildlife habitat or plant communities? }\end{array}$ & $\begin{array}{c}\text { Not at All } \\
\text { Compatible } \\
4 \%\end{array}$ & $\begin{array}{c}\text { A Little } \\
\text { Compatible } \\
9 \%\end{array}$ & $\begin{array}{c}\text { Somewhat } \\
\text { Compatible } \\
36 \%\end{array}$ & $\begin{array}{c}\text { Very } \\
\text { Compatible } \\
51 \%\end{array}$ \\
\hline $\begin{array}{l}\text { d. Do you think that grazing can be useful for reducing fire } \\
\text { hazard? }\end{array}$ & $\begin{array}{c}\text { Not at All } \\
\text { Useful } \\
4 \%\end{array}$ & $\begin{array}{c}\text { A Little } \\
\text { Useful } \\
16 \%\end{array}$ & $\begin{array}{c}\text { Somewhat } \\
\text { Useful } \\
12 \%\end{array}$ & $\begin{array}{c}\text { Very Useful } \\
67 \%\end{array}$ \\
\hline
\end{tabular}

Participants were also asked to comment on the conference, telling us what they learned that would be useful to them, and how we might improve this type of forum. We were pleased to find that responses were overwhelmingly positive. Some of the most useful things participants learned were how conservation organizations are working with ranchers, and about the possibilities of ranchers as environmental partners. Participants especially appreciated the discussion of concrete, ground-tested tools for increasing and protecting biodiversity in a working landscape, including grass banking, improved grazing management, and conservation easements. Participants wanted more tools, and a broad approach that went beyond ranching and across disciplines. Other kinds of working landscapes could be included, in the opinion of some. The participation of conservation groups was highly valued.

The forum got many of the participants thinking about incentives for private conservation, especially given the current economics of agriculture in California. Some commented that they felt much better informed about the barriers facing continued ranching. A couple of people were disappointed that the forum did not address public land management issues.

Most respondents valued the opportunity to network with others, and to find such a diverse group with a common interest in landscape conservation. One rancher commented that he or she learned the need for working and visiting with those who don't understand ranching or ranch land. Respondents stated that they came away with an increased desire to spend more time building community, and developing common goals with landowners and other community stakeholders. At future meetings, they want to see more and broader participation from a variety of environmental groups, Resource Conservation Districts, and government planners.

The next step, many agreed, was to get down to the nuts and bolts of how to accomplish specific conservation goals, and to develop policy actions that would help. One respondent would have liked more information about the amount and character of grazing in the Bay Area.

\section{Working Landscapes Will Require Working Together}

Participants came looking for ways to develop constructive compromise for land conservation. We believe this reflects the pool of invitees-most had some practical experience in land conservation, in one way or another, and were acquainted with its complexities. For future programs, participants want more broad participation, and more intense workshops on the specifics of the tools for encouraging land conservation on private lands.

The forum itself accomplished some important goals. People learned more about working landscapes, and gained an appreciation of both the problems and the opportunities 
Table 6. Responses changing significantly as a result of the forum (percentages rounded).

\begin{tabular}{|c|c|c|c|c|}
\hline Question: & $\begin{array}{l}\text { Before the } \\
\text { Forum }\end{array}$ & $\begin{array}{l}\text { After the } \\
\text { Forum }\end{array}$ & $\begin{array}{l}\text { Before the } \\
\text { Forum }\end{array}$ & $\begin{array}{l}\text { After the } \\
\text { Forum }\end{array}$ \\
\hline $\begin{array}{l}\text { How successful would maintaining a viable ranching community be } \\
\text { for wildlife conservation and landscape conservation in the } \\
\text { Bay Area? }\end{array}$ & $\begin{array}{c}\text { Somewhat } \\
\text { Successful } \\
\text { (BEFORE) } \\
\mathbf{2 5 \%} \\
\end{array}$ & $\begin{array}{c}\text { Somewhat } \\
\text { Successful } \\
\text { (AFTER) } \\
29 \% \\
\end{array}$ & $\begin{array}{c}\text { Very } \\
\text { Successful } \\
\text { (BEFORE) } \\
\mathbf{3 7 \%}\end{array}$ & $\begin{array}{c}\text { Very } \\
\text { Successful } \\
\text { (AFTER) } \\
\mathbf{5 2 \%}\end{array}$ \\
\hline $\begin{array}{l}\text { How successful would conservation easements be for wildlife } \\
\text { conservation and landscape conservation in the Bay Area? }\end{array}$ & $\begin{array}{c}\text { Somewhat } \\
\text { Successful } \\
\text { (BEFORE) } \\
44 \%\end{array}$ & $\begin{array}{c}\text { Somewhat } \\
\text { Successful } \\
\text { (AFTER) } \\
\mathbf{3 1 \%} \\
\end{array}$ & $\begin{array}{c}\text { Very } \\
\text { Successful } \\
\text { (BEFORE) } \\
38 \% \\
\end{array}$ & $\begin{array}{c}\text { Very } \\
\text { Successful } \\
\text { (AFTER) } \\
\mathbf{6 5 \%} \\
\end{array}$ \\
\hline How familiar are you with the concept of a working landscape? & $\begin{array}{c}\text { Somewhat } \\
\text { Familiar } \\
\text { (BEFORE) } \\
\mathbf{3 5 \%}\end{array}$ & $\begin{array}{c}\text { Somewhat } \\
\text { Familiar } \\
\text { (AFTER) } \\
\mathbf{3 3 \%}\end{array}$ & $\begin{array}{c}\text { Very } \\
\text { Familiar } \\
\text { (BEFORE) } \\
\mathbf{3 0 \%}\end{array}$ & $\begin{array}{c}\text { Very } \\
\text { Familiar } \\
\text { (AFTER) } \\
\mathbf{6 3 \%} \\
\end{array}$ \\
\hline $\begin{array}{l}\text { How likely do you think it is that ranching has long term future in } \\
\text { the Bay Area? }\end{array}$ & $\begin{array}{c}\text { Somewhat } \\
\text { Likely } \\
\text { (BEFORE) } \\
31 \% \\
\end{array}$ & $\begin{array}{c}\text { Somewhat } \\
\text { Likely } \\
\text { (AFTER) } \\
\mathbf{5 8 \%} \\
\end{array}$ & $\begin{array}{l}\text { Very Likely } \\
\text { (BEFORE) } \\
10 \%\end{array}$ & $\begin{array}{c}\text { Very } \\
\text { Likely } \\
\text { (AFTER) } \\
6 \% \\
\end{array}$ \\
\hline
\end{tabular}

in using private rangeland management as a means of conserving open land. We believe that we did increase support for the multiple-use agriculture-based working landscape concept - participants were more favorably inclined toward consideration of the welfare of the ranching community in developing land conservation programs at the end of the meeting. Further, the networking that many participants mentioned as a valuable part of the concept should further extend and maintain this support. Working to maintain contact with participants and to continue to share information with them will be important.

The problems facing California are not unique. Our experience leads us to believe that the concept of working landscape can facilitate communication among diverse groups that share a common interest in land conservation and good stewardship. Ranchers and conservationists need to work together for incentive-based conservation strategies to work, and a setting that allows for discussion and mutual learning is needed. Community forums such as this can:
1. increase understanding of working landscapes (barriers as well as opportunities);

2. catalyze local/regional action;

3. broaden on-going information sharing, particularly among government agencies and non-governmental organizations;

4. increase the role of the ranching community and other agriculturalist and landowners in developing land conservation programs; and

5. demonstrate broad stakeholder commitment to working landscapes.

\section{About the authors:}

Sheila Barry and Lynn Huntsinger, Bay Area Natural Resources Advisor, UCCE Santa Clara County, 700 Empey Way, San Jose, California 95128, and Associate Professor, Department of Environmental Science Policy, and Management, University of California, Berkeley California 94720.

For more information, contact Sheila Barry, UCCE Santa Clara, 700 Empey Way, San Jose, CA 95128. email: sbarry@ucdavis.edu Fax: 408-298-5160 